\title{
The Twists and Turns of State Universities with Legal Entity Status (PTN-BH) as a Form of Decentralization of Higher Education in Indonesia
}

\author{
Abd. Qadir Muslim*, Andhyka Muttaqin, Aulia Luqman Aziz, Dhea Monica Setia Putri, Arina Izza Sabila \\ Educational Administration Program, Faculty of Administrative Science \\ Universitas Brawijaya \\ Malang, Indonesia \\ *qadirmuslim@ub.ac.id
}

\begin{abstract}
In the Fourth Industrial Revolution era (Industry 4.0), everything is required to be flexible, including a bureaucratic system, especially in the education bureaucracy where education is a pillar in the progress of the nation because education is in direct contact with the nation's next generation. Today, the government continues to do its best and to seek innovation to create an attractive, non-monotonous, and flexible education world according to the needs of the times. If in the past all decisions were left to the central government, now in accordance with the times, it has been delegated for effectiveness. This is known as decentralization, where there is a devolution of authority from the central government to the regions to regulate and manage their own affairs. Thus, decentralization enters every field of national development, one of which is education. With the existence of decentralization in the education sector, education has the flexibility according to the location of its autonomy whether in regions, schools, or universities to make decisions and utilize existing resources without having to violate protocols from the central government. This paper used a qualitative approach and used library research or content analysis as research method, namely by discussing the results of previous studies which discussed the decentralization of higher education. The results showed that the main key to the success of this decentralization of education is the existence of cooperation and accountability of every activity and educational process carried out. However, in fact, this decentralization is not easy, there are still many pros and cons in its implementation, especially how the implementation of decentralization in higher education, namely state universities with PTN-BH status (state universities with legal entity status) are a form of educational commercialization. In fact, PTN-BH is still being continued. Even the Minister of Education and Culture has made it easy for universities wishing to change their status to become a legal entity.
\end{abstract}

Keywords-education decentralization policy, education autonomy, PTNBH

\section{INTRODUCTION}

In this era, an education system is forced to continue to develop and keep up with the changing times. The education system is demanded to be flexible, effective, and efficient. This happens not only due to the current development era but also due to the characteristics of Indonesia with all the potential as a Unitary State consisting of thousands of islands. On the other hand, the change in the government system, which started from a centralized government into a decentralized system, was marked by the enactment of the Regional Autonomy Law number 22 of 1999 and later was refined by Law number 32 of 2004 concerning Regional Government. This signifies the handover of authority that was originally the authority of the central government to become the authority of the regional government. The implementation of regional autonomy has changed various aspects in Indonesia including the decentralization of education. Nowadays, both formal and nonformal education is very important to build the nation's foundation because education builds and shapes the image of the younger generation. Considering several things related to the development of democratic society and social capital as well as the competitiveness of the nation, education decentralization is important [1].

Those three things are the driving force for the implementation of decentralization in the education sector. To make the implementation of regional autonomy run smoothly and successfully, especially in the field of education, qualified human beings are needed. This is in accordance with the function of Indonesian education as stated in Law number 20 of 2003 concerning the National Education System which says that the function of education is to be a noble, healthy, knowledgeable, skilled, creative, accountable, and democratic human being who believes and has faith in God Almighty. In other words, it is highly expected that education can help the formation of qualified human beings for the development of the nation, especially in regional areas which are given the authority to develop, manage, and integrate local culture into the area of education so that a balance between national knowledge and local knowledge can be built. To realize this hope, all reform efforts are being made by the government through the increase of decision and policymaking, management paradigm, educational resources management, 
curriculum development, financial management, and evaluation mechanisms in all educational processes. With the existence of Law number 32 of 2004 concerning Government Decentralization, one of the areas that have been decentralized in the education sector in the form of School-Based Management (Manajemen Berbasis Sekolah, abbreviated as MBS). MBS is a form of independence to create and manage each level of education unit according to the circumstances, needs, and potentials of the school; and are expected to be able to develop the existing potentials optimally. This is not separated from the flexibility of a school leader in managing power and stimulating community participation to improve the quality of education [2].

To realize an effective school decentralization, school leaders need to acquire innovative skills in leadership and management which focuses on financial affairs, teachers, and the surrounding communities. The decentralization that has been implemented in Indonesia still has several regional gaps in education development. This includes the gaps in school facilities, number of teachers, school participation, and illiterate population. However, it still can be said that the overall decentralization has brought changes to improve education development across the region. With the continuing decentralization of education, it is believed that the remaining gaps can be reduced [3].

Like school decentralization that leads to MBS, higher education also attempts to implement an effective decentralization. In the level of higher education, the autonomy is held by the higher education institution to regulate its continuity of education. Higher education is believed to be part of the national education system which has a strategic role in educating and advancing science and developing a humanities environment for students. Higher education, which is implemented through six types of institutions, has a strategic meaning to create the nation's competitiveness in facing globalization in various fields. Therefore, several efforts are needed so that higher education will be able to develop science and technology as well as creating intellectual, knowledgeable, cultured, creative, tolerant, democratic, defined, and brave individuals to defend truth for the benefit of the nation (Renstra Kemendikbud year 2010). When viewed from the Strategic Plan of the Ministry of Education and Culture, the freedom of higher education institutions to achieve its objectives is in the form of its autonomy to implement education. This is stated in article 24 of Law number 20 of 2003 that (1) in the implementation of education and development of science, higher education institutions have the academic freedom and scientific autonomy, (2) higher education institutions have the autonomy to manage their own institutions as centers for the implementation of education, scientific research, and community service, (3) higher education institutions can obtain sources of funds from the community whose management is based on the principle of public accountability, and (4) the provisions regarding the implementation of higher education as referred to in Paragraph 1, Paragraph 2, and Paragraph 3 shall be further regulated by government regulations.
The challenge in this matter is to make the autonomy policy of higher education continue to be stronger in the implementation of Law number 12 of 2012 concerning Higher Education. Law number 12 of 2012 is an improvement of Law number 9 of 2009 concerning Education Legal Entities (Badan Hukum Pendidikan, abbreviated as BHP) and Government Regulation number 17 of 2010 concerning Education Management and Implementation which in fact have quite a lot of challenges from educational stakeholders. Moreover, this government regulation is even being canceled by the Constitutional Court of Indonesia [4].

To date, the government continues to strive in creating and improving the relevance of higher education so that it can produce graduates with skills and expertise required for the rapidly developing and undergoing structural changes in today's highly competitive global economy. It is hoped that the existence of decentralization in the education sector will be able to create a new education system, especially in higher education institutions. The presence of state universities with legal entities (PTN-BH) as part of the decentralization in the education sector is also expected to create a superior generation. However, in fact, there are many pros and cons to this higher education autonomy, especially PTN-BH in its implementation.

\section{METHODS}

In this paper, the researchers used a qualitative approach through the identification of literature related to the concept of educational decentralization and PTN-BH. The analysis of the data was done using library research or content analysis that is discussing the results of previous studies that discussed the decentralization in education policy and reality in the application of PTN-BH.

\section{RESULTS AND DISCUSSION}

\section{A. Educational Decentralization in Indonesia}

Decentralization in the Indonesian Dictionary (Kamus Besar Bahasa Indonesia, abbreviated as KBBI) is defined as a government system that gives more power to the regional government. Article 1 Point 7 of Law number 32 of 2004 concerning the Regional Government sees decentralization as the transfer of authority from the central government to autonomous regions to regulate and manage the government system. This happened with delation. Seen from the field of education, and educational decentralization is a systematic process in which the lower institution receives or gets an authority to implement the education process. This contains the use of all facilities, policy formulation, financing, and independent decision-making.

Educational decentralization is one form of the education reform process. This decentralization is included in the realm of educational autonomy. According to Article 8 of Law of National Education System number 20 of 2003, in the chapter of Rights and Obligations of Citizens, Parents, Society, and 
Government, it is stated the community has the right to participate in planning, implementing, monitoring, and evaluating the educational program. Whereas, in Article 9, it is stipulated that the community is obliged to provide support in the form of natural resources for the implementation of education. The fourth chapter of Article 11 Paragraph 2 concerning the Rights and Obligations of the Central Government and Local Government explains that the government must guarantee the availability of funds for the implementation of education for every citizen aged seven to fifteen. As for higher education, Article 24 Paragraph 2 said that higher education institutions have the autonomy to manage their own institutions as centers of education, scientific research, and community service activities. From the explanation above, the concept of educational autonomy has a broad meaning. Each autonomous region has a clear and longterm vision and mission for the education system with plans to answer every educational challenge.

The autonomous management of education is assumed to have an impact on the equalization of access to education as well as the improvement of quality and relevance of educational financial efficiency and administrative efficiency. The decentralization in the education sector requires a strong, transparent, and efficient democratic foundation that involves stakeholders. Conceptually, there are two types of educational decentralization, decentralization of authority in terms of education policies and its funding aspects from the central government to local governments (provincial, district/city) and decentralization which focuses on granting greater authority at the school level. The first concept of educational decentralization is mainly related to regional autonomy and the decentralization of governance from the center to the regions. On the other hand, the second one focuses on granting greater authority at the school level. That is carried out to improve the quality of educational outcomes.

In China, the decentralization of education was not only caused by political changes but there are other general processes that have had and still influencing it. Among them, the development of computerization, globalization, and the knowledge-based economy in the world. These factors have a strong effect on the development of Chinese society in the fields of economics, science, technology, culture, and especially higher education. With these developments and economic transition, all aspects of Chinese higher education have undergone profound changes to meet the challenges of international competition and to adapt higher education management to the needs of China's socialist modernization construction. As a result, the administration of higher education in China has been reformed at three levels: national, institutional, and subdivisional [5].

\section{B. The Purpose of Educational Decentralization}

By looking at the cases of educational decentralization in other countries, it can be noted that the aims and orientation of educational decentralization are varied. The goal of decentralization is the granting of greater authority in the field of education to local governments. Therefore, the focus of educational decentralization is on the transfer of greater authority to local governments or to education councils and/or school committees.

One implicit thing in this decentralization strategy is to achieve efficiency in resource empowerment (personnel, materials, and education funds from the government and the community). Vice versa, if the objective of this effort is to improve the quality of the teaching and learning process and its outcomes, the decentralization of education will be more focused on reforming the teaching and learning process.

The decentralization of education that has been implemented in several countries also has various objectives. One case of educational decentralization in Taiwan showed that a change in education management is characterized by campus-based management [6]. In this case, it is important to ensure stakeholder participation in the decision-making process if decentralization is to enforce and maintain democracy in higher education. Meanwhile, in Germany, decentralization encourages innovation and regulation in several mechanisms. The first is that it reduces the dimensions of the higher education system; this helps to innovate in the system and to maintain consensual decision-making rules which are an important feature of the higher education system. In this way, stakeholders in a consensual system can always act as a veto player to block a change. Second, decentralization governs decision-making and levels of operation. It improves the quality of information available to decision-makers and discourages collusion of local alliances whose aim is to gather resources for specific purposes in contrast to the welfare of the system. Still, the crucial importance of decentralization reform has two main objectives which are the redistribution of funds and the improvement of student achievement [7].

\section{Steps to Achieve the Success of Educational Decentralization}

In achieving the success of educational decentralization, the first thing to do is to apply deregulation that is the need to reduce and/or add regulations to spur the effectiveness of educational decentralization in each region. This deregulation is aimed to increase flexibility and eliminate the bureaucratic chains that are too slow. Secondly, it needs decentralization performed in stages and a continuous manner so that it is in accordance with the original planning and in accordance with the objectives to be achieved. Number three, it is crucial to apply a democratic and participatory leadership system in organizing and implementing the educational process. Finally, always keep in mind to uphold the principles of transparency, accountability, and professionalism in the implementation of education decentralization.

\section{Decentralization in Higher Education}

It is a concern that the full autonomy of higher education through the status of PTN-BH cannot achieve the goals of national education. In the formulation of Higher Education Law, it is mentioned that "the autonomy of higher education 
becomes one of the prerequisites for the expected major role to run well and be able to demonstrate good and acceptable accountability to the general public". The Constitutional Court of Indonesia in its decision chose to cancel the BHP Law. They argued that in UUD 1945, it is already explained that to achieve educational objectives that are in accordance with Pancasila and UUD 1945, an autonomous education management system is not needed. Even worse, the Constitutional Court of Indonesia sees educational autonomy as only trial and error without any empirical study of what has failed the achievement of national education goals (Baharuddin: 2019). This is like the results of a study entitled Decentralization and reform of higher education. Can Germany be an example for Italy? In an essence, the policy of granting autonomy for higher education in Germany had a significant impact on the country but this was not successful in Italy. This happened certainly due to several things such as the ability and capacity of the state that is not the same [8].

By that, the interpretation of the Constitutional Court of Indonesia for this strategy is clearly problematic. On one side, this is an injection of interests from international financial institutions that have the interest to include the logic of the free market in the management of higher education. While on the other hand, this has nothing to do with our national educational goals.

\section{E. PTN-BH in the Flow of Globalization}

The flow of globalization that is growing from time to time will never be able to stop. This situation is like the law of the nature that humans will always follow the direction of the pace, wherever it goes. Globalization will certainly affect various aspects of human life. This condition makes any government in many countries incorporate several essential elements for the current and future aspects of governance including education. Education is the main axis for the government to develop its human resources so that they can face the challenges of the future. Likewise, Indonesia with its abundant natural resources must be prepared and not to forget, develop the human resources. The quality of human resources can characterize a country whether it has good quality or not. This is seen from its human development index. Hence, it can be said that education is a vital tool for a state to improve its quality. In facing globalization, the researchers see the direction of education development in Indonesia, one of which is the emergence of PTN-BH status (state universities with legal entity status) which has drawn a lot of controversy from academics and society. PTN-BH as a form of educational reform has become a crucial issue in Indonesia after 1998. Globally, this issue is also developing in other countries. This first emerged from the discourse offered by the World Bank and World Trade Organization to reform their higher education regulations which are essential to relinquish the state's responsibility to the education sector and leave it to the market mechanism. However, there is a case that has had bad consequences. This case occurred in North Carolina in which the legislative and coordinating boards made the decision to decentralize the aspects of tuition policy that serve to deregulate higher education and leave it to the market. In its implementation, a market cannot operate without an appropriate market culture. Given its history and mission, UNC-Chapel Hill cannot build a market culture to enable them to operate in a market they find quickly. Simply put, the institution, policies, and leaders did not have a strong foundation, beliefs, assumptions, and values to successfully navigate the market. There was this one time where the policy for tuition fees has changed and most universities were not worried about competing in the market, they had no experience in how to do it effectively. The administrators and faculty did not reach an agreement on how to operate in a market environment without compromising the values and beliefs of various stakeholders [9]. The existence of PTN-BH is a form of the state trying to reduce its role in the education sector and leaving it to the external institutions but without any readiness.

There are two major discourses that dominate the development of higher education in the world. The first is called the globalization of higher education (by the World Trade Organization) and the second is the reform of higher education (by the World Bank). In the GATS agreement 1994, it is noted that higher education is one of the services sectors to be liberalized and Indonesia is included in it. Of course, the policy from the World Trade Organization is intended to open the door for investors to put down shares of higher education cooperation [10]. This confirms that PTN-BH is a form of neoliberalism, and this has plagued the education system in Indonesia. On the other hand, the World Bank has made a breakthrough on the higher education reform agenda since the policy framework document entitled "Higher Education: Lessons of Experience" was published. The essence of the agenda encourages 4 things including (1) differentiation of institutions; (2) differentiation of funding from the public; (3) redefining the role of government; and (4) focusing on performance and equality. In the Higher Education Law, the issues regarding the development of the two institutions are seen in several articles. Article 86 says that the government facilitates the business world and the industrial world by actively providing financial assistance to Higher Education. Meanwhile, Article 65 explains the authority to establish business entities and develop century funds. Article 85 signifies that higher education is financed by students whereas Article 89 clarifies the funding for state university's legal entities. Most strikingly, Article 90 mentions that higher education is implemented regarding state universities from other countries. This discourse is very logically linked to the discourse of globalization offered by the World Trade Organization and the World Bank. By looking at the formulation of Higher Education Law, the government stated that "to increase competitiveness in global interactions, it is necessary to have universities that are healthy, qualifies, autonomous, and advanced". The keywords of competitiveness deliver educational reforms that are liberal, pro to the market, and free from state interference. 


\section{F. Educational Commercialization}

Higher education with PTN-BH status will have the autonomy in regulating its own education system including its finances. PTN-BH is given the authority to obtain funds to support the university apart from the government budget. The funding from a business entity established by the university is an entry point for investors. Reduced funding from the government will cause PTN-BH to seek maximum funds from the private sector. Of course, this funding assistance from the private sector will be very beneficial for the university. However, in the end, the university must be willing to be intervened by external corporations. For example, several PTN-BH have fast-food restaurants or prestigious coffee shops. This is certainly not a problem for middle-upper economics students, but this is not the case for middle-lower economics students. It would be very detrimental, especially if the food stalls in the canteen are replaced by fast-food restaurants with expensive dishes. In the end, the education will be trapped in the flow of capitalization and commercialization. This will lead to the assumption that the educational institution will be determined by the owner of the capital or investors in the PTN$\mathrm{BH}$ and will cause the practice of nepotism. The stakeholders from the private sector can influence the decision-making or regulations issued by the university because they are shareholders and have a large amount of capital. In this position, it is unethical not to include them in the top ranks and, potentially, they will propose decisions/regulations which are in line with their economic motives. This practice of neoliberalism in the form of educational capitalization implies that the educational practice is a form of economic control by the elite.

Private actors in PTN-BH certainly add to the dynamics of universities where these universities will compete to compare and improve campus infrastructure. Fulfilling the quality of a world-class university is very difficult because it needs high resources and funds. The process towards a world-class university will make the role of the government smaller due to managerial requirements and funding origins. One result of this situation is that PTN-BH can open a larger quota on Jalur Mandiri (independent student registration path) than the Jalur Undangan (invitation path); Jalur Mandiri demands higher tuition fees. This is of course because the university has the authority to determine the tuition fees for students from Jalur Mandiri. As a result, access to higher education is limited for the lower-class society making it not in line with the concept that education is a public good. This has reduced the independence of education in Indonesia and injures the nation's ideals that are to educate the nation's life. Education should be inclusive, not exclusive. It should be accessible to all layers of society. This can be evidenced by studies on Higher Education Law. The discharge of the state's responsibility in terms of funding is reflected in the Higher Education Law. There are articles that implicitly say that the government regulates the technical management but leaves the funding to students, the business world, and the public. This is supported by Article 83 which states that the government "can" provide financial support. That "can" term is interpreted by the Constitutional
Court of Indonesia as something that is not an obligation but as an option. Of course, the government will have the opportunity to discharge its responsibility in the process. Then, Article 88 addressed the standard unit operating costs that will be used by the university to determine students' tuition fees. In this article, there is no clarity of regulations and guarantees of people's rights in education freedom. Furthermore, there is Article 86 which provides funding opportunities from the business world through incentives and facilitation and Article 89 which states clearly that PTN-BH funding comes from a government budget.

The consequence of this funding system is, of course, the exemption of society in education costs. This has the potential to cut off the access of the poor to higher education by which this is not in accordance with the constitution (Article 31 of UUD 1945). Consequently, education cannot free them from poverty and ignorance.

\section{G. PTN-BH as a Ticket to Realize World-Class University}

Education is a public area. In the context of global competition towards a world-class university, the task of a public sector is to build an institution for stakeholders in the education sector (profit-oriented or non-profit stakeholders) to develop and be competitive. The best public policy is to initiate the community to build competitiveness and not pushing to the pattern of dependence [11].

The existence of PTN-BH status will lead related universities to have fierce competition so that to win the competition, universities must determine their quality in every academic and non-academic activity. In the end, the output from higher education in the form of graduates and scientific research will be beneficial and attract the eye of stakeholders. To organize academic and non-academic activities, universities should have adequate infrastructures through the provision of full autonomy so that they will be more flexible in organizing the activities. This is done to improve the quality of their outcomes. Whereas, to compete in this rapidly growing era, universities may use external stakeholders/business entities to provide a market overview that is needed by the world today. From there, universities can carry out research and innovation to produce output that is relevant to the current or future era. With full autonomy, universities can expand their market segmentation not only in their own country but also in the global world. The key is to create higher education values and develop them into international and standardized institutional culture [12].

PTN-BH also gives the authority to establish a new study program that is expected to be in accordance with the market needs. One of the issues in this matter is the gap between universities and the industrial world. Many graduates of certain study programs are reported to not have the skills and expertise needed by the market. This resulted in a large amount of unemployment. With the authority to establish new study programs, the gap between universities and the world of the industry will disappear. Universities can carry out their role as research and innovation institutions and the industrial world 
can take advantage of domestic research potentials to develop their competitiveness. That way, the establishment of a new study program will be separated from the bureaucratic flow that has been complicated. This will become simpler but, of course, still needs an empirical study from the board of trustees.

\section{H. The Focus of Higher Education that has been Complete}

Based on data from PDDIKTI, there are currently 4670 universities in Indonesia, including State Universities and Private Universities. At present, around 95\% of universities are still focused on teaching. This shows the lack of academic's attention to develop science through scientific publications in the form of international journals. Seen on the Scimago Lab website which ranks publications from 239 countries around the world, Indonesia is in the $48^{\text {th }}$ position with 110,610 publications. This number is far from other ASEAN countries such as Singapore ( $32^{\text {nd }}$ position) with a total of 292,560 publications and Malaysia ( $34^{\text {th }}$ position) with 286,411 publications. From the website, it can be known that the most productive level was the United States with a total of $12,070,144$ publications and China 5,901,404 publications. This is certainly interesting to see the basic problems of higher education productivity in Indonesia.

With the emergence of PTN-BH autonomy, higher education institutions have encouraged themselves to develop the quality of their knowledge, especially in the aspects of research results. This aspect will be evaluated to see the productivity in the contribution of publications so that they can be included in the top 500 categories. In 2013, Indonesia was in the $61^{\text {st }}$ position with a total of 25,481 publications. It can be said that the status of PTN-BH is able to increase the volume of research publications making Indonesia at the $48^{\text {th }}$ rank with a total of 110,610 publications. Currently, the PTN-BH that have succeeded in registering their name in the top 500 ranks are Universitas Indonesia (previously on the $345^{\text {th }}$ position and now on $296^{\text {th }}$ position) and Institut Teknologi Bandung (was originally on the $445^{\text {th }}$ position and now is at $331^{\text {st }}$ position).

The lack of publication of international reputable journals is of course caused by several things that have caused Indonesia to be left behind from others. However, in general, it can be concluded that scientific works have not fully become an important asset for higher education. This can be seen from the absence of awards for lecturers/researchers who have successfully published their journals in international reputation. To publish internationally, it really requires an effort because of the strict selection. Besides that, the limited sources of power and funds to produce qualified scientific works is also a big challenge for academicians because they must be supported by qualified international references as well. Among other countries, Indonesia has the lowest investment in research. The budget allocation is only about $0.09 \%$ of GDP. This is far from other countries that allocate the investment $\mathrm{u}$ to $1.47 \%$ (Thailand), $1.47 \%$ (China) (Qian X; 2004), and $0.6 \%$ (Malaysia). Also, not all universities in Indonesia able to provide a workspace that is productive for lecturers. The research culture in the Indonesian academic environment is still very little. This will have an impact on those who cannot fully think about the affairs of scientific publications.

Some research results suggest that the quality of education could be higher in the decentralized model rather than in the centralized model. This is since the decentralized regime could allow students with good grades to enter college reinforced with expenditures made by all regions which may exceed the expenditures of the central government. However, this outcome will be uncertain if the central government decides to apply a decentralized educational system. This will make the related parties depend on the existence and size of fixed funds and will have the potential to influence the access of students to higher education/universities [13].

\section{CONCLUSION}

Educational decentralization is a systematic process in which the lower institution receives or gets an authority to implement the education process. This contains the use of all facilities, policy formulation, financing, and independent decision-making. It is hoped that the provision of full autonomy for higher education through the status of PTN-BH will increase the effectiveness in achieving the national goals of education. In this regard, it is important to ensure stakeholder participation in the decision-making process if decentralization is to uphold and maintain democracy in higher education. However, in fact, the decentralization of education in higher education has created many pros and cons in the community. Seen from the positive responses, decentralization makes universities have tickets to world-class universities. With the existence of PTN-BH status, it will lead related universities to compete fiercely so that to win it, universities must determine their quality in every academic and nonacademic activity. On the contrary sides, a higher institution with PTN-BH status will have the autonomy to regulate the course of its own education system including its finances. PTN-BH is given the authority to obtain funds to support the university apart from the government budget. The funding from a business entity established by the university is an entry point for investors. Reduced funding from the government will cause PTN-BH to seek maximum funds from the private sector. This funding assistance from the private sector will be very beneficial for the university. However, in the end, the university must be willing to be intervened by external parties. The twists and turns of PTN-BH are a hot topic in every university. PTN-BH gives the authority to establish a new study program that is expected to be in accordance with the market needs. One of the issues to date is the gap between universities and the industrial world. It is reported that many graduates of certain study programs do not have the skills and expertise needed by the market. This resulted in a large amount of unemployment.

\section{REFERENCES}

[1] H.A.R. Tilaar, Membenahi Pendidikan Naional, 2002. 
[2] J.S. Mwinjuma, A. Hamzah and R. Basri, "A review of characteristics and experiences of decentralization of education," International Journal of Education and Literacy Studies, vol. 3, no. 1, pp. 34-41, 2015.

[3] W. Winardi, "Decentralization of education in Indonesia-A study on education development gaps in the provincial areas," International Education Studies, vol. 10, no. 7, pp. 79-93, 2017.

[4] C.M. Lasambouw, "Analisis Kebijakan Tentang Otonomi Perguruan Tinggi dalam Bentuk Badan Hukum Pendidikan," Sigma-Mu (Jurnal Penelitian \& Gagasan Sains Dan Matematika Terapan), vol. 5, no. 2, pp. 37-54, 2013.

[5] X. Qian and J.C. Verhoeven, "From centralization to decentralization in Chinese higher education," Education policy analysis archives, vol. 12, no. 67, 2004.

[6] W.Y.W. Lo, "Decentralization of higher education and its implications for educational autonomy in Taiwan," Asia Pacific Journal of Education, vol. 30, no. 2, pp. 127-139, 2010.
[7] J. Moon, "HISD's Decentralization Reform (Part II: Principal Survey)," Research Brief for the Houston Independent School District, vol. 6, no. 3, 2018.

[8] G. Ballarino, "Decentralization and reform of higher education. Can Germany be an example for Italy?" Italian Journal of Sociology of Education, vol. 3, no. 2, 2011.

[9] M.S. Harris, "From policy design to campus: Implementation of a tuition decentralization policy," Education Policy Analysis Archives/Archivos Analíticos de Políticas Educativas, vol. 15, pp. 1-20, 2007.

[10] D.G. Hawkins, D.A. Lake, D.L. Nielson and M.J. Tierney, Delegation and agency in international organizations. Cambridge University Press, 2006.

[11] D. Nugroho, Public policy. Jakarta: Elex Media Komputindo, 2008.

[12] N. Nurdin, "Pro-kontra Undang-undang Bhp Dalam Konteks Mutu Pendidikan," Jurnal Administrasi Pendidikan, vol. 9, no. 1, 2009.

[13] J. Rosselló-Villalonga, "Does Decentralization in the Provision of Higher Education Increase Quality of Education?" Hacienda Pública Española/Review of Public Economics, vol. 220, no. 1, pp. 13-55, 2017. 